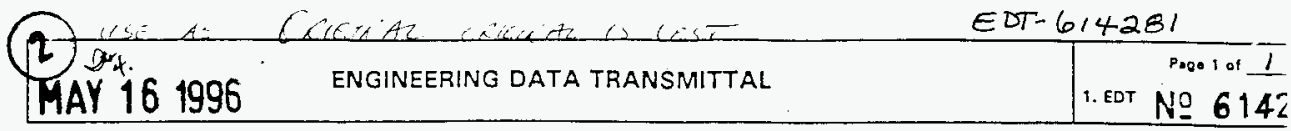

\begin{tabular}{|c|c|c|c|c|c|c|c|c|}
\hline \multicolumn{3}{|c|}{$\begin{array}{l}\text { 2. To: (Receiving organization) } \\
\text { Tank Farm Transition } \\
\text { Projects }\end{array}$} & \multicolumn{2}{|c|}{$\begin{array}{l}\text { 3. Fron: (originating organization) } \\
\text { Transition Projects } \\
\text { Integration Program }\end{array}$} & \multicolumn{4}{|c|}{$\begin{array}{r}\text { 4. Related EOT KO.: } \\
\qquad \mathrm{W} / \mathrm{A}\end{array}$} \\
\hline \multicolumn{3}{|c|}{$\begin{array}{l}\text { 5. Proj.prog./0ep:.10iv.: } \\
\text { Tank Farm Transition } \\
\text { Projects }\end{array}$} & \multicolumn{2}{|c|}{$\begin{array}{l}\text { 6. cog. Engr.: } \\
\text { R. W. Jacobson }\end{array}$} & \multicolumn{4}{|c|}{$\begin{array}{l}\text { 7. Purehase Drdar No.: } \\
\qquad N / A\end{array}$} \\
\hline \multirow{2}{*}{\multicolumn{5}{|c|}{$\begin{array}{l}\text { 8. criginator Remarks: } \\
\text { Document is being issued for approval and release }\end{array}$}} & \multicolumn{4}{|c|}{$\begin{array}{c}\text { 9. Equip./Compcrent No.: } \\
\text { W/A }\end{array}$} \\
\hline & & & & & \multicolumn{4}{|c|}{$\begin{array}{r}\text { 10. system/ales./Facility: } \\
\mathbb{N} / \mathrm{A}\end{array}$} \\
\hline \multirow{3}{*}{\multicolumn{5}{|c|}{ i1. Receiver Remarks: }} & \multicolumn{4}{|c|}{$\begin{array}{r}\text { 12. Major Assm. Dwg. No.: } \\
\mathrm{N} / \mathrm{A}\end{array}$} \\
\hline & & & & & \multicolumn{4}{|c|}{$\begin{array}{c}\text { 13. Permit/Permi: Applicaticn No.: } \\
\text { W/A }\end{array}$} \\
\hline & & & & & \multicolumn{4}{|c|}{ 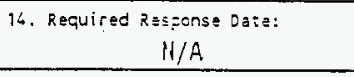 } \\
\hline \multicolumn{5}{|c|}{ 15. OATA IIUVSMETES } & (F) & (6) & (H) & (1) \\
\hline $\begin{array}{l}\text { (A) } \\
\text { trem } \\
\text { No. }\end{array}$ & (B) Documentidorawir.s No. & $\begin{array}{l}\text { (C) } \\
\text { Sh:set } \\
\text { No. }\end{array}$ & $\begin{array}{l}101 \\
\text { Fis. } \\
\text { ilo. }\end{array}$ & $\begin{array}{c}\text { IE Tise in Description of Cata } \\
\text { Transmitted }\end{array}$ & $\begin{array}{l}\text { ApFroval } \\
\text { Desig: } \\
\text { nator }\end{array}$ & $\begin{array}{c}\text { Ressen } \\
\text { fer } \\
\text { Tisins: } \\
\text { minim: }\end{array}$ & $\begin{array}{l}\text { O:izi- } \\
\text { nator } \\
\text { Dispo- } \\
\text { sition } \\
\end{array}$ & $\begin{array}{l}\text { Rese } \\
\text { er } \\
\text { Dispe. } \\
\text { sitizer. }\end{array}$ \\
\hline 1 & $\begin{array}{l}\text { WHC-SD-H/314-R.PT- } \\
003\end{array}$ & & 0 & $\begin{array}{l}\text { Tank Farm Restoration } \\
\text { and Safe Operations, } \\
\text { Project W-314, } \\
\text { UpgradE Scope Summary } \\
\text { Report }\end{array}$ & $M / A$ & 1 & & \\
\hline
\end{tabular}

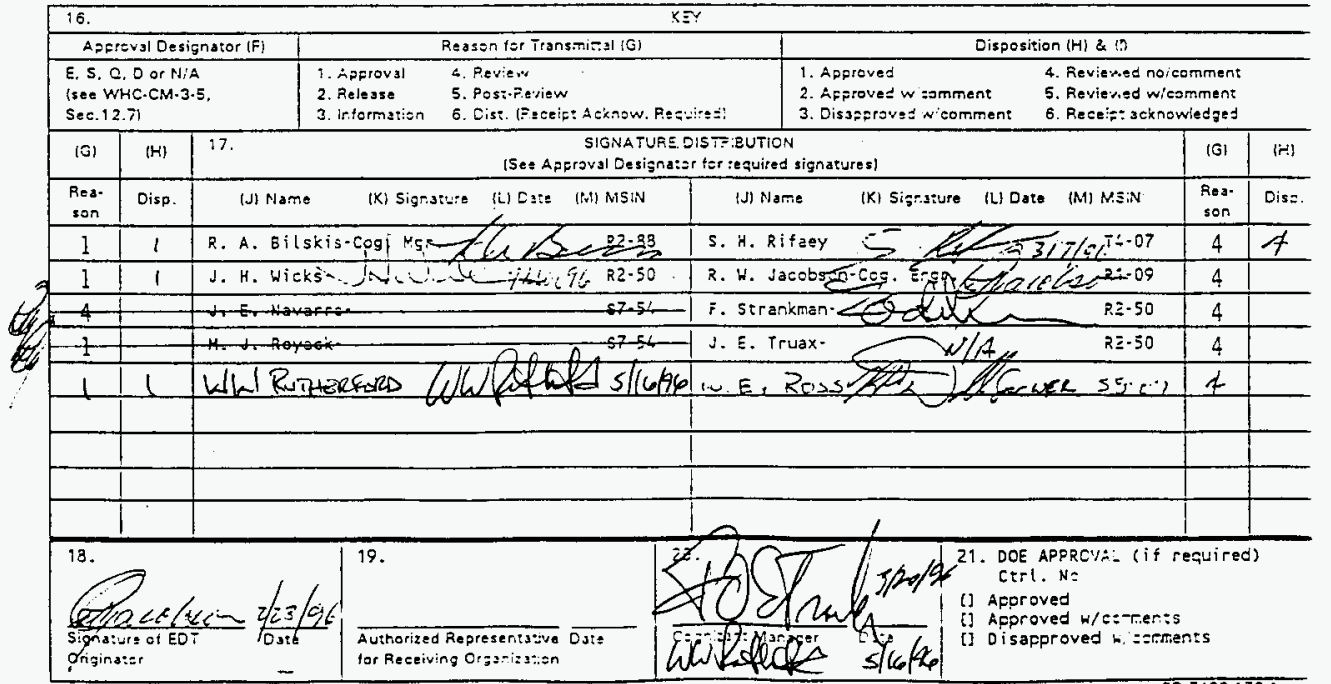




\title{
Tank Farm Restoration and Safe Operations, Project W-314, Upgrade Scope Summary Report
}

\author{
R. A. Bilskis
}

Westinghouse Hanford Company, Richland, WA 99352

U.S. Department of Energy Contract DE-AC06-87RL10930

$\begin{array}{ll}\text { EDT/ECN: } 614281 & \text { UC: } \\ \text { Org Code: } 77680 & \text { Charge Code: NI4PG } \\ \text { B\&R Code: } & \text { Total Pages: } 3132 \mathrm{kmB} 6 / 15 / 96\end{array}$

Key Words: The Tank Waste Remediation Systems (TWRS), Project W-314, Upgrade Scope Summary Report (USSR)

Abstract: The Tank Farms Transition Projects organization, Transition Projects Integration Program (TPIP) Upgrade Scope Summary Report (USSR) describes the scope of work to be accomplished by Project W-314. It defines the facility, the system and the actual upgrade that corrects deficiencies and addresses needs in the tank farms and provides a matrix giving traceability to the requirement or driver for the specific activity.

TRADEMARK DISCLAIMER. Reference herein to any specific comercial product, process, or service by trade name, trademark, manufacturer, or otherwise, does not necessarily constitute or imoly its endorsement, recomendation, or favoring by the United states Government or any agency thereof or its contractors or subeontractors.

Printed in the United states of America. To obtain copies of this document, contsct: WHC/BCS Document Control Services, P.0. Box 1970, Mailstop H6-08, Richland HA 99352. Phone-(509) 372-2420; Fax (509) 376-4989.
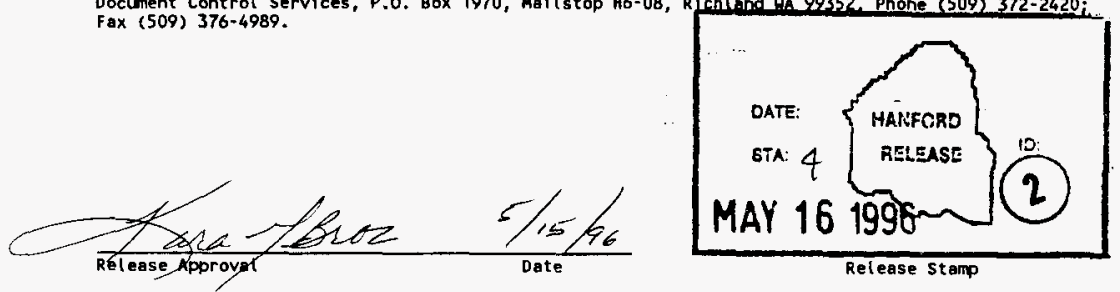

Approved for Public Release 
WHC-SD-W314-RPT-003

Revision 0

\title{
U.S. DEPARTMENT OF ENERGY HANFORD SITE
}

\author{
TANK FARM RESTORATION \\ AND SAFE OPERATIONS (TFRSO)
}

PROJECT W-314

UPGRADE SCOPE SUMMARY REPORT

February 23, 1996

Prepared for:

U.S. Department of Energy

Richland Operation Office

Richland, Washington 99352

Prepared by:

Westinghouse Hanford Company

Post Office Box 1970

Richland, Washington 99352 
WHC-SD-W314-RPT-003

Revision 0

TFRSO PROJECT W-314

UPGRADE SCOPE SUMMARY REPORT

\section{TABLE OF CONTENTS}

\section{EXECUTIVE SUMMARY}

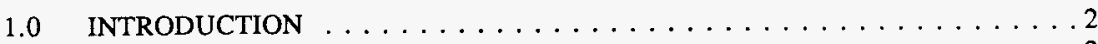

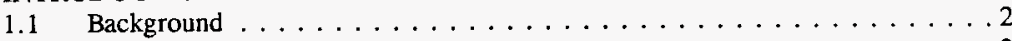

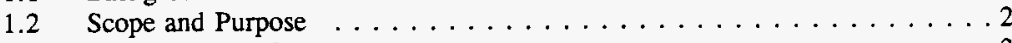

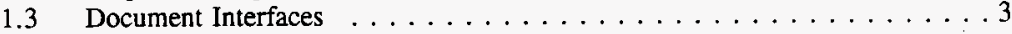

2.0 UPGRADE SCOPE SUMMARY $\ldots \ldots \ldots \ldots \ldots \ldots \ldots \ldots \ldots$

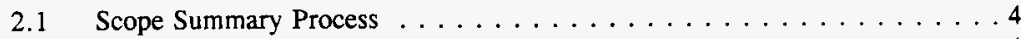

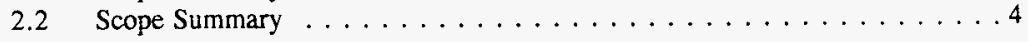

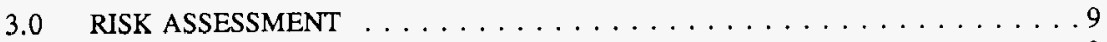

3.1 Methodology . . . . . . . . . . . . . . . . 9

3.2 Factors Affecting the Risk Assessment $\ldots \ldots \ldots \ldots \ldots \ldots$

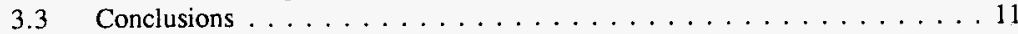

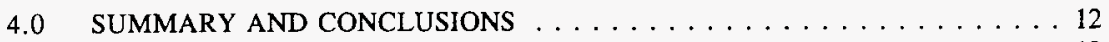

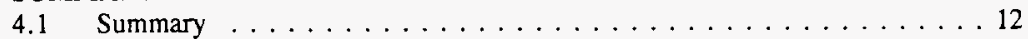

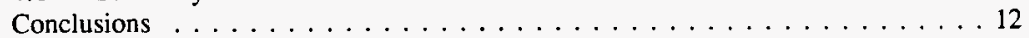

\section{APPENDIX}
A. Definitions
B. References
C. Upgrade Scope Summary Table 
WHC-SD-W314-RPT-003

Revision 0

TFRSO PROJECT W-314

UPGRADE SCOPE SUMMARY REPORT

\section{EXECUTIVE SUMMARY}

The Upgrade Scope Summary Report (USSR) is a sequential element document of the systems engineering process that is utilized to identify and provide a summary of the scope items (including systerns, subsystems, and/or components) that require upgrading for a facility. The W-314 Project USSR was prepared to address items identified to be within the W-314 project scope resulting from the evaluations, inspections and assessments conducted on the Tank Farms facilities. The W-314 Project USSR was included in the project baseline as a key element of W-314 and is specifically designed to define the scope on which to develop a conceptual design report, and to support the infrastructure necessary for the TWRS mission of managing tank waste, while addressing known and defined future requirements.

Section 1 provides the Introduction for this document. This section contains general information on how and why the USSR was conducted, the background information that was used to define the scope, and establish the basis of how the USSR is integrated into the document hierarchy for the W-314 Project. Section 2, Upgrade Scope Summary, provides an overview of the Transition Project Integration Program scoping process and specific scope elements. A synopsis of the risk assessment efforts for this task are presented in Section 3. Section 4 is the Actions and Requirements, which describes the future mission requirements, interface with the subsequent Detailed Assessment, and conclusions of the scoping process.

Appendix $\mathrm{A}$ lists and identifies the acronyms and abbreviations contained in this document. Appendix B provides a listing of references germane to the USSR effort. Appendix $C$ provides a crosswalk from the specific scope items in the USSR to the requirement or driver that determined inclusion in the scope. 
WHC-SD-W314-RPT-003

Revision 0

\author{
TFRSO PROJECT W-314 \\ UPGRADE SCOPE SUMMARY REPORT
}

\title{
1.0 INTRODUCTION
}

This section provides general information on how and why the USSR was conducted, the background information that was used to establish the scope, and presents the rationale for how the USSR fits into the document hierarchy for the W-314 Project.

\subsection{Background}

The mission of the Tank Waste Remediation System (TWRS) program is to store, treat, and immobilize highly radioactive tank waste in an environmentally sound, safe, and cost-effective manner. Within this program, the Tank Farm Restoration and Safe Operations (TFRSO) Project W-314, a Major Systems Acquisition, will provide major upgrades in the areas of instrumentation and control, tank ventilation, waste transfer, and electrical distribution for existing tank farm facilities. This project has completed the pre-conceptual design phase and has received Key Decision 0 authorization to proceed with the next project phase.

The purpose of the W-314 Project is to restore and/or upgrade existing Tank Farms facilities and systems to ensure that the Hanford Tank Farm infrastructure will be able to safely manage tank waste and support known future requirements. The capital improvements provided by this project will increase the margin of safety for Tank Farms operations, and will aid in aligning affected Tank Farm systems with compliance requirements from applicable, state, Federal, and local regulations. Secondary benefits will be realized subsequent to project completion in the form of reduced equipment down-time, reduced health and safety risks to occupational workers, and minimization of exposure to the environment from radioactive and/or hazardous material releases.

In accordance with the Systems Engineering Statement of Work (SE-SOW) Approach Review for Project W-314, Tank Farm Restoration and Safe Operations (WHC-SDW314-SOW-003, 06/08/95), this Upgrade Scope Summary Report (USSR) was prepared as a requirement for the completion of Decision Point Review No. 2 (DPRH2). 
WHC-SD-W314-RPT-003

Revision 0

\subsection{Scope and Purpose}

As stated from the SE-SOW, the W-314 Upgrade Scope Summary Report should be:

". . a summary of the Tank Farm Infrastructure upgrade scope required to support TWRS. Format and content shall be determined by the performing contractor. Volume of the report should be limited to no more than about $25-30$ pages. The report shall be a stand-alone document but shall also be included as part of the Master Plan ..."

The USSR is a key element required for defining the scope of Project W-314 .

A working draft of the USSR was released on November 3, 1995. This provided an initial scope from which to initiate the Conceptual Design Report (CDR) activity. Subsequent to this, additional information has been presented to help further define the scope. This generation of Revision 0 of the USSR, WHC-SD-W314-RPT-003 represents an accumulation of these activities and finalizes the scope of the project from which the CDR is being developed.

\subsection{Document Interfaces}

The USSR provides a key link between the evaluation of existing conditions and required upgrades (presented in the Facilities Assessment Summary Report, or FASR) and the Detailed Assessment. The primary input documents for USSR are the FASR and the four Initial Assessment Reports.

W-314 FASR was prepared as a summarized report that documents the process used to determine acceptability or deficiency status of the systems, subsystems and/or components appraised during the initial systems assessments.

The FASR provides a key link between the gathering of data to describe the existing conditions and required upgrades and the description of the upgrade work scope. Input documents include (among others) the Mission Analysis Report, Condition Assessment Surveys, Resource Allocation Sheets, and the Project W-314 Preliminary Design Requirements Document (PDRD). The FASR will be used as the basis to develop the Upgrades Scope Summary Report, which defines the specific scope to develop the CDR. 
WHC-SD-W314-RPT-003

Revision 0

The FASR task involved the utilization of both historical and real-time evaluations to determine the status and conditions of the systems, subsystems, and components within the W-314 project. At this initial (preliminary) stage of project development, information was gathered that would allow Operations to review and approve the project scope.

\subsection{UPGRADE SCOPE SUMMARY}

The systems inspection and assessments conducted for the TFRSO Project W-314 provided the information utilized as the basis of the FASR. This systems assessment overview included walkdowns of the pertinent facilities, interviews, studies, and evaluations as needed to define the existing conditions and requirements for upgrades. The resulting upgrade requirements formulated the scoping process that determined items to be included in the $\mathrm{W}$ 314 Project.

\subsection{Scope Summary Process}

The primary objectives of the system assessment were to determine if the functionality of existing systems is sufficient to fulfill the mission needs defined in the Preliminary Design Requirements Document (PDRD) and to determine if the life expectancy of the existing systems would be sufficient for the mission duration. The PDRD was started using four earlier engineering studies and was expanded utilizing the initial assessments to define the system functionality required to meet the mission for a duration of 30 years. The categories involved were:

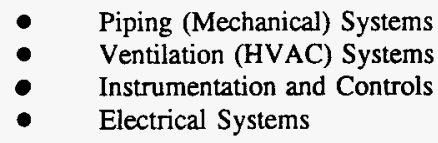

The screening process conducted during the development of the FASR identified two types of requirements and related scopes of work; those that are to be included in the W-314 Project, and those to be excluded from the W-314 Project (the 'Other' category). This USSR identifies the items that are to be identified in the W-314 Project scope. 
WHC-SD-W314-RPT-003

Revision 0

\subsection{Scope Summary}

The elements of work to be included in the W-314 Project scope are presented in detail in the Functions Assessment Tables (FATs) that were developed during the initial assessment activities.

The criteria used to define the scope of W-314 are as follows:

1. Systems shall be provided and/or upgraded to support the Manage Tank Waste (MTW) function and to support TPA milestones.

2. Systems shall be designed in such a manner as to ensure safety in the following areas:
a. Off-Site Exposure
b. Environment Exposure
c. Personnel Safety
d. System Safety

3. Systems shall perform such that the tank farm mission to Manage Tank Waste is satisfied (i.e. meets requirements documented in PDRD).

4. Systems shall be capable of performing requirements for the duration of the mission.

5. Systems shall comply with legal/regulatory constraints (ref. PDRD).

6. Systems shall be capable of efficient operation as measured in terms of:
a. Reliability, Availability, Maintainability
b. Operability

7. System modification and replacement decisions shall consider life cycle costs in the areas of:
a. Design
b. Construction
c. Operations
d. Support 
WHC-SD-W314-RPT-003

Revision 0

\subsubsection{Piping}

The scope of work for piping covers the following:

- All central pump pits and valve pits/diversion boxes along the waste transfer routes for double-shell tanks will be upgraded with a protective coating in order to meet all decontaminability and/or regulatory compliance criteria. The protective coating will be applied to: Valve pits AN-A, AN-B, A-A, A-B, AX-A, AX-B, Sluice pit AZ-02B.

- New manifold jumper arrangements in selected valve and pump pits to provide a greater degree of flexibility in transfer routes, reduce jumper changeout and maintenance requirements, and minimize personnel exposure. ICF $\mathrm{KH}$ will consider alternate valve operating systems (i.e., "Teleflex") over current practices. The manifold jumper arrangements will inciude: Valve pits AN-A, AN-B, A-A, A-B, AX-A, AX-B; and Sluice pit AZ-02B.

- New transfer lines compatible with the new cross site transfer line and the privatization needs ( 3 " lines recommended) will be provided to support projected waste transfer operations between the following locations:

(1) Valve pit AN-B to Sluice pit AZ-02B

(2) Sluice pit AZ-02B to Valve pit AX-A

(3) Vaive pit A-A to Valve pit AW-A

- Replace the following transfer piping:

(1) Line $\mathrm{SN}-216$

(2) Line $S N-213 / 200$

(3) Line SL-502

(4) Line SL-504

\subsubsection{Piping Assumptions}

1. Fabricated liners will not used, since the special protective coating to be used in the identified pits meets all applicable regulatory compliance issues for containment.

2. Jumper manifold upgrades for the AW Tank Farm valve pits are provided by Project W-454.

3. Line SL-180 (transfer line from SY-A valve pit to SY-B valve pit) is being repiaced by Project W-211. 


\section{WHC-SD-W314-RPT-003}

Revision 0

4. The new transfer lines provide the required transfer routing and volume as defined in the waste volume projections for MTW and known Privatization needs.

5. Line SL-503 is being replaced by an existing ICF $\mathrm{KH}$ Work Order.

6. The new transfer lines will not be provided with heat tracing.

7. The SY Valve pits do not require valve manifolds due to jumper arrangements provided by Project W-211.

\subsubsection{HVAC}

The scope of work includes upgrading the primary ventilation systems for AN, AP, and $\mathrm{AW}$ Tank Farms, the annulus ventilation systems for $\mathrm{SY}$ farm, and the complete ventilation systems for DCRT's 244-A and 244-S. The ventilation systems will include seal pot and drainage systems, and filtration systems. The new ventilation systems will be modular in design to permit any or all of the gaseous effluent treatment requirements as identified in the PDRD.

This selection of a modular type system was derived from the preliminary results of the architectural development process currently in progress for W-314.

\subsubsection{HVAC Assumptions}

1. The design will be modular to the extent that special effluent treatment devices (such as absorbers for organics and/or ammonia control) can be easily connected in the future to support all possible transfer situations.

2. The HVAC design will assume that upgraded ventilation equipment will be removed, where practicable, with the new equipment located in a nearby area.

3. The new primary ventilation equipment will be generic to, AN, AP, and AW Tank Farms; capacity may be adjusted to suit each individual farm. The DCRT's require new designs.

4. The primary ventilation systems are assumed safety class 2 for confinement and safety class 3 for operation. The annulus ventilation system is assumed safety class 3 , safety class 2 for operations.

5. Cooling systems needed during retrieval will be modular and independent of the ventilation systems, and installed by retrieval projects.

6. Upgraded systems will utilize existing ducting where possible. 


\subsubsection{Instrumentation and Control}

The scope of work includes new and/or upgraded instrumentation for tank monitoring for all DST's, the 244-A and 244-S DCRTs, tank and waste transfer leak detection system upgrade, an information management system, and the master pump shutdown system upgrade.

The following items will be replaced and will be monitored with the signal provided for monitoring and/or control as required:

1. Replace the manual tape method of annulus leak detection in DST's with better technology.

2. Replace the SpG-WF method of annulus leak detection in the DCRT's with better technology.

3. Upgrade the CAM annulus leak detectors in DST's and DCRT's with new models.

4. Replace the SpG-WF method of determining DST leak detection pit leak with better technology This method will be applied to a dry pit.

5. Upgrade the DST leak detection pit radiation detectors to withstand the physical environment.

6. Alarm DST leak detection pit high liquid level.

7. Alarm high liquid level in DST's.

8. Replace existing clean out box leak detectors systems with an operationally testable system.

9. Replace existing primary pipeline leak detectors with an operationally testable system in the DST farms and DCRT's transfer pits and pipeline encasements.

10. Verify waste transfer routing through the use of pipeline pressure and/or valve position, and/or pipeline flow monitoring as required on routing between the DST farms and the DCRT's.

11. Install magnetic flowmeters for incoming and outgoing transfer lines for tanks AN-101, 102, 103, 104, 105, 106, 107; AP-101, 102, 104; AW-101, 104, 105; AZ-101, 102; AY-102; and SY-101, 102 in support of privatization

12. Install waste transfer valve position indicators on Valve Pits AN-A, AN-B, 241-AP, AW-A, AW-B; Pump Pits AN-01A through 07A, AP-01A, AP-04A, AP-02A, AP-02D, AW-01A, AW-04A, AW-05A, AY-02A, AZ-01A, AZ02A; Sluice Pit AZ-02B; and SY Pits 241-SY-A, 241-SY-B, SY-01A, and SY$02 \mathrm{~A}$ in support of privatization. 
WHC-SD-W314-RPT-003

Revision 0

13. Upgrade the master pump shutdown system to use operationally testable components and to replace the relay based approach in the DST farms and SST farms as specified.

14. Upgrade the master pump shutdown relay panel in the 242-A and upgrade and move the panel out of the 242-S evaporators.

15. Raw water flow for DST's and DCRT's service pits, including turbine flowmeters in the AN, AP, AW, AY, and SY service pits to support privatization.

16. Raw water radiation (backflow detection) at the DCRT's service pit.

17. Provide leak detection of new piping.

18. Tank waste specific gravity, temperature, and liquid level in the DST's and the DCRT's.

19. Tank primary vapor space pressure in DST's and the DCRT's.

20. Primary ventilation train pre-filter and HEPA filter differential pressures, exhaust temperature, and exhaust heater differential pressure for all DST farms except AY and AZ, and the 244-A DCRT.

21. Install the WHC "Gaseous Effluent Monitoring System" at the AW, SY, AN and AP primary ventilation exhaust stack.

22. Input DST farm annunciated signals ("Panalarm") into a centralized monitoring system.

23. Replace the existing "Game-Well" remote alarm monitoring with alarm displays in the DST farms.

24. Connect selected existing alarms from the A, BY, C, SX, and U farms; and CR-271, 242-T, 244-AR, and 204-AR facilities for input to the TMACS.

25. Move selected monitor and controls from the $242-S$ control room.

\subsubsection{Instrumentation and Control assumptions}

1. We will use the WHC developed/supplied stack monitor specification for each installation where required.

2. All instrumentation will be safety class 3 .

3. Scope of $242-S$ control room demolition is based on 76 points found on the control room instrumentation panel drawing $\mathrm{H}-2-46436$. The 76 points identified do not include any signals pertaining to the 242-S building (ventilation filter pressures...); and does not include any "GAMEWELL" or "CASS" signals that remain to be identified. The signals moved will only be those associated with the Tank Farms (i.e., buildings are excluded). W-314 will not ensure the associated equipment is operational. 


\section{WHC-SD-W314-RPT-003 \\ Revision 0}

4. TMACS will continue to be utilized.

5. A separate Information Management System (IMS) will not be provided. Any IMS functions required can be accommodated by TMACS and SACS.

6. All signals from the Tank Farms will be monitored in the local instrument building as well as at $2750 \mathrm{E}$ Bldg by TMACS.

7. The 244-S facility is the equivalent of the 244-A for purposes of this CDR.

8. Assume the existing signals to be connected to the TMACS (Section 1, Item 22) are connected to a "Panalarm" annunciator.

9. Leak detection of privatization tanks is a TWRS responsibility.

\subsubsection{Electrical}

The scope of work for electrical includes upgrades to electrical equipment and wiring as required throughout the DST farms and the 244-A and 244-S DCRT's. These upgrades will include the following:

1. Replacement of existing MCC's, vent and heater control panel with new units in the 241-AY and 241 AZ Tank Farms and the 244-A DCRT.

2. Upgrade and/or provide backup power system for the primary ventilation system and stack monitors for Tank Farms 241-AN, AP, and AW.

3. Replace existing feeder of $244-S$ by providing a new pad-mounted $13.8 \mathrm{kV}$ transformer.

4. Provide SST's power systems to support controlled, clean, and stable and to refeed existing lights and miscellaneous instrumentation such as TMACS.

5. Spare main circuit breakers for AN, and AW Tank Farms.

6. Provide cathodic protection for new piping.

7. Provide freeze protection for seal pots and drainage systems installed by $W$ 314.

\subsubsection{Electrical assumptions}

1. All electrical power will be safety class 3 power.

2. The existing $13.8 \mathrm{KV}$ utility feeders have enough capacity to meet the demands for existing and future power requirements. 
WHC-SD-W314-RPT-003

Revision 0

\subsection{RISK ASSESSMENT}

As required by the SE-SOW, a preliminary Risk Assessment was conducted in support of the initial assessment activities. The assessment was conducted to fulfill the requirements of the SE SOW WBS Item 1.3.2, Risk Analysis, and the Contractor WBS Item F.1.1.2, System Assessment Risk Report. The risk assessment is concerned with the credibility of the system assessment, particularly as it relates to the determination of the scope of the Project W-314. Key factors in evaluating the credibility of the assessment include the methodology of the assessment, the degree of confidence in the conclusions of the assessment for specifying the condition of the tank farms, and the risk these conditions pose to the project. The risk to the project would be manifested as scope change later in the design, with attendant cost and schedule impacts.

The system assessment is to be conducted in two phases, initial and detailed. Therefore, the risk assessment is also conducted in two phases.

\subsection{Initial Risk Assessment}

The risk assessment methodology used to develop the Risk Report was generally based on expert opinion, augmented by consideration of key risk indicators. Information acquired in response to the questions posed by the risk indicators is a direct indication of the credibility of the process being examined. For example, a process that commences with a well documented, thorough plan which has been promulgated to all participants is more likely to produce credible results than one which develops as the action is conducted. This does not stipulate that the latter approach is not without some value. The risk assessment for the TFRSO initial assessment was conducted in a manner that maintains cognizance of the fact that the material condition of the tank farm is generally well known. Thus the primary purpose of the system assessment, as it relates to the Project W-314, is to assess the condition of the tank farm systems, structures, and components specifically as to their capability to satisfy requirements of the PDRD.

\subsection{Final Risk Assessment}

The second phase of Risk Assessment will be performed utilizing the Transition Projects and TWRS Risk Management Plans. Documentation of the results will be in accordance with approved procedures. 


\section{WHC-SD-W314-RPT-003}

Revision 0

\subsection{SUMMARY AND CONCLUSIONS}

The scope analysis summarized in this document represents the preliminary determination of which upgrade systems are required within the scope of the W-314 Project. The results of this scoping effort will support Detailed Assessment and the subsequent master planning activities.

\subsection{Summary}

The USSR provides the basis for the subsequent Detailed Assessment and conceptual design activities (post-DPR $\# 2$ actions). The information provided in Section 2 identifies the scope elements for the W-314 Project. Additional information will be developed (via trade studies, engineering analyses, etc.) during the Detailed Assessment to further define and clarify scope elements to support definitive design activities.

\subsection{Conclusions}

Based on an evaluation of the information contained in the IAR's, the PDRD, and presented in the FASR, the following have been concluded:

1. The PDRD provides the requirements that define the scope for the W-314 Project.

2. The scope provided in the USSR is adequate to support the initiation of conceptual design activities.

3. The scope of the W-314 Project will be further defined during the Detailed Assessment process. This is not expected to significantly affect the conceptual design phase of the project.

4. The development of the TPIP will not affect the mission of the W-314 Project. 


\section{WHC-SD-W314-RPT-003}

Revision 0

\section{APPENDIX A ACRONYMS AND ABBREVIATIONS}

DCRT Double Contained Receiver Tank

DOE-RL Department of Energy, Richland Operations Office

DPR Design Point Review

DRD Design Review Document

DST Double Shell Tank

FASR Facility Assessment Summary Report

FAT Functions Assessment Table

F\&OR Functions and Operational Requirements

MAR Missions Analysis Report

PDRD Preliminary Design Review Document

PDRD $+\quad$ Revised Preliminary Design Review Document

RAS Resource Allocation Sheets

SE $\quad$ Systems Engineering

SOW Statement of Work

SSC Systems, Subsystems and Components

TFRSO Tank Farm Restoration and Safe Operations

TPIP Transition Project Integration Program

USSR Upgrade Scope Summary Report 


\title{
WHC-SD-W314-RPT-003
}

Revision 0

\author{
APPENDIX B \\ REFERENCES
}

- WHC-SD-W314-ES-023, Project W-314 Facility Assessment Summary Report (FASR), Rev 0, 11/01/95

- WHC-SD-W314-ES-018, Project W-314 DST and DCRT Instrument and Control Systems, Initial Assessment (Acree 1995)

- WHC-SD-W314-ES-020, DST and DCRT Rank Farm Electrical Distribution Systems Initial Assessment (Golberg 1995)

- WHC-SD-W314-ES-021, Initial Assessment Report for Mechanical Systems Upgrade (Mattichak 1995)

- WHC-SD-W314-ES-022, Initial Assessment Report, HVAC Systems (Kriskovich 1995)

- $\quad$ WHC-SD-W314-DRD-002, LATA Preliminary Design Requirements Document (PDRD) Draft 10/95 
WHC-SD-W314-RPT-003

Revision 0

APPENDIX C

TFRSO PROJECT W-314

UPGRADE SCOPE SUMMARY TABLE

\begin{tabular}{|c|c|c|c|}
\hline Section & Category & Description & Requirement \\
\hline $\begin{array}{c}\text { USSR } 2.2 .1 \\
\text { TWRS SE } \\
4.2 .1 \\
\text { W-314 SE } \\
4.2 .1 .3\end{array}$ & Piping & $\begin{array}{l}\text { All central pump pits and valve pits/diversion boxes } \\
\text { along the waste transfer routes for double-shell tanks } \\
\text { will be upgraded with a protective coating in order to } \\
\text { meet all decontaminability and/or regulatory compliance } \\
\text { criteria. The protective coating will be applied to: } \\
\text { - Pump pits AN-01A, AN-02A, AN-03A, } \\
\text { AN-04A, AN-05A, AN-06A, and AN-07A. } \\
\text { Valve pits AN-A, AN-B, A-A, A-B, AX-A, } \\
\text { AX-B } \\
\text { Sluice pit AZ-02B }\end{array}$ & $\begin{array}{l}\text { Safety Not required for safety. } \\
\text { Compliance 10CFR61.41, ALARA. If secondary } \\
\text { containment has been breached, a liner or repair is } \\
\text { required. Specific tasks will be determined by } \\
\text { inspection of each unit. } \\
\text { Privatization Valve Pits AN-A \& AN-B and Sluice } \\
\text { Pit AZ-02B support Privatization } \\
\text { Conduct of Operations Reduce personnel } \\
\text { exposure, operating, and maintenance costs by } \\
\text { shortening decontamination time. }\end{array}$ \\
\hline
\end{tabular}


WHC-SD-W314-RPT-003

Revision 0

\begin{tabular}{|c|c|c|c|}
\hline Section & Category & Description & Requirement \\
\hline $\begin{array}{c}\text { USSR } 2.2 .1 \\
\text { TWRS SE } \\
4.2 .1 \\
\text { W-314 SE } \\
4.2 .1 .3\end{array}$ & Piping & $\begin{array}{l}\text { Install new manifold jumper arrangements in selected } \\
\text { valve and pump pits to provide a greater degree of } \\
\text { flexibility in transfer routes, reduce jumper changeout } \\
\text { and maintenance requirements, and minimize personnel } \\
\text { exposure. The manifold jumper arrangements will } \\
\text { include: } \\
\text { Valve pits AN-A, AN-B, A-A, A-B, AX-A, } \\
\text { and AX-B } \\
\text { Sluice pit AZ-02B. }\end{array}$ & $\begin{array}{l}\text { Safety Not required for safety. } \\
\text { Compliance 10CFR61.41, ALARA. } \\
\text { Privatization Supports AN and AP privatization } \\
\text { requirements. In order to meet TPA milestones } \\
\text { the Arena Model shows the need for simultaneous, } \\
\text { multiple transfers and the ability to quickly setup } \\
\text { new transfer routes. } \\
\text { Conduct of Operations Reduce personnel } \\
\text { exposure, operating, and maintenance costs by } \\
\text { eliminating pit entry for jumper changeout. Support } \\
\text { privatization and accelerate the tank farms closure } \\
\text { by about three years. }\end{array}$ \\
\hline $\begin{array}{c}\text { USSR } 2.2 .1 \\
\text { TWRS SE } \\
4.2 .1 \\
\text { W-314 SE } \\
4.2 .1 .3\end{array}$ & Piping & $\begin{array}{l}\text { Install new transfer lines compatible with the new cross } \\
\text { site transfer line (3" lines recommended) to suppost } \\
\text { projected waste transfer operations between the } \\
\text { following locations: } \\
\text { Valve pit AN-B to Sluice pit AZ-02B } \\
\text { Sluice pit AZ-02B to Valve pit AX-A } \\
\text { Valve pit A-A to Valve pit AW-A }\end{array}$ & $\begin{array}{l}\text { Safety Not required for safety. } \\
\text { Compliance No compliance issues identified. } \\
\text { Privatization Supports AN and AP privatization } \\
\text { requirements. } \\
\text { Conduct of Operation Add waste routing } \\
\text { flexibility, and support accelerated tank farms } \\
\text { closure. }\end{array}$ \\
\hline
\end{tabular}


WHC-SD-W314-RPT-003

Revision 0

\begin{tabular}{|c|c|c|c|}
\hline Section & Category & Description & Requirement \\
\hline $\begin{array}{l}\text { USSR } 2.2 .1 \\
\text { TWRS SE } \\
4.2 .1 \\
\text { W-314 SE } \\
4.2 .1 .3\end{array}$ & Piping & $\begin{array}{ll}\text { Replace the following transfer piping: } \\
\text { Line SN-216 } \\
\text { Line SN-213/200 } \\
\text { Line SL-502 } \\
\text { Line SL-504 }\end{array}$ & $\begin{array}{l}\text { Safety Not required for safety. } \\
\text { Compliance No compliance issues identified. } \\
\text { Privatization Supports AN and AP privatization } \\
\text { requirements. } \\
\text { Conduct of Operation Allow transfer lines to } \\
\text { operate at full capacity and avoid premature line } \\
\text { failure due to pipe erosion. Support accelerated } \\
\text { tank farms closure. }\end{array}$ \\
\hline $\begin{array}{l}\text { USSR } 2.2 .2 \\
\text { TWRS SE } \\
4.2 .1 \\
\text { W-314 SE } \\
4.2 .1 .1 \\
4.2 .1 .3\end{array}$ & HVAC & $\begin{array}{l}\text { Upgrade the primary ventilation systems for AN, AP, } \\
\text { and AW Tank Farms. The ventilation systems will } \\
\text { include seal pot, drainage, and filtration systems. }\end{array}$ & $\begin{array}{l}\text { Safety Not required for safety. } \\
\text { Compliance tOCFR61.41, ALARA. Provide } \\
\text { compliant ventilation system with stack monitoring } \\
\text { Privatization Filtration upgrades support potential } \\
\text { transfers in support of privatization. } \\
\text { Conduct of Operations Reduce personnel } \\
\text { exposure, operating, and maintenance costs by } \\
\text { minimizing farm entry and replacing unreliable } \\
\text { equipment. }\end{array}$ \\
\hline
\end{tabular}


WHC-SD-W314-RPT-003

Revision 0

\begin{tabular}{|c|c|c|c|}
\hline Section & Category & Description & Requirement \\
\hline $\begin{array}{c}\text { USSR } 2.2 .2 \\
\text { TWRS SE } \\
4.2 .1 \\
\text { W-314 SE } \\
4.2 .1 .1 \\
4.2 .1 .3\end{array}$ & HVAC & $\begin{array}{l}\text { Upgrade the annulus ventilation system for } S Y \text { farm. } \\
\text { The ventilation systems will include seal pot, drainage, } \\
\text { and filtration systems. }\end{array}$ & $\begin{array}{l}\text { Safety Not required for safety. } \\
\text { Compliance 10CFR61.41, ALARA. Provide } \\
\text { organic compliant ventilation system with stack } \\
\text { monitoring. } \\
\text { Privatization No privatization requirements } \\
\text { identified. } \\
\text { Conduct of Operations Reduce personnel } \\
\text { exposure, operating, and maintenance costs by } \\
\text { minimizing farm entry and replacing unreliable } \\
\text { equipment. }\end{array}$ \\
\hline $\begin{array}{c}\text { USSR } 2.2 .2 \\
\text { TWRS SE } \\
4.2 .1 \\
\text { W-314 SE } \\
4.2 .1 .1 \\
4.2 .1 .3\end{array}$ & HVAC & $\begin{array}{l}\text { Upgrade the ventilation systems for DCRT's } 244-A \text { and } \\
244-S \text {. The ventilation systems will include seal pot, } \\
\text { drainage, and filtration systems. }\end{array}$ & $\begin{array}{l}\text { Safety Not required for safety. } \\
\text { Compliance 10CFR61.41, ALARA. Provide } \\
\text { compliant ventilation system with stack monitoring. } \\
\text { Privatization No privatization requirements } \\
\text { identified. } \\
\text { Conduct of Operations Reduce personnel } \\
\text { exposure, operating, and maintenance costs by } \\
\text { minimizing farm entry and replacing unreliable } \\
\text { equipment. }\end{array}$ \\
\hline
\end{tabular}


WHC-SD-W314-RPT-003

Revision 0

\begin{tabular}{|c|c|c|c|}
\hline Section & Category & Description & Requirement \\
\hline $\begin{array}{c}\text { USSR } 2.2 .3 \\
\text { TWRS SE } \\
4.2 .1 \\
\text { W-314 SE } \\
4.2 .1 .1 \\
4.2 .1 .3\end{array}$ & $\begin{array}{l}\text { Instrumentation } \\
\text { and Control }\end{array}$ & $\begin{array}{l}\text { Replace the manual tape method of annulus leak } \\
\text { detection in DST's with better technology. }\end{array}$ & $\begin{array}{l}\text { Safety Not required for safety. } \\
\text { Compliance 40CFR265.193, detection of leaks to } \\
\text { secondary containment within } 24 \text { hours. } \\
\text { Privatization No privatization requirements } \\
\text { identified. } \\
\text { Conduct of Operations Reduce personnel } \\
\text { exposure, operating, and maintenance costs by } \\
\text { minimizing farm entry for data collection and } \\
\text { eliminating unreliable instruments. }\end{array}$ \\
\hline $\begin{array}{c}\text { USSR } 2.2 .3 \\
\text { TWRS SE } \\
4.2 .1 \\
\text { W-314 SE } \\
4.2 .1 .1 \\
4.2 .1 .3\end{array}$ & $\begin{array}{l}\text { Instrumentation } \\
\text { and Control }\end{array}$ & $\begin{array}{l}\text { Replace the SpG-WF method of annulus leak detection } \\
\text { in the DCRT's with better technology. }\end{array}$ & $\begin{array}{l}\text { Safety Not required for safety. } \\
\text { Compliance 40CFR } 265.193 \text {, detection of leaks to } \\
\text { secondary containment within } 24 \text { hours. } \\
\text { Privatization No privatization requirements } \\
\text { identified. } \\
\text { Conduct of Operations Reduce personnel } \\
\text { exposure, operating, and maintenance costs by } \\
\text { minimizing farm entry for data collection and } \\
\text { eliminating unreliable instruments. }\end{array}$ \\
\hline
\end{tabular}


WHC-SD-W314-RPT-003

Revision 0

\begin{tabular}{|c|c|c|c|}
\hline Section & Category & Description & Requirement \\
\hline $\begin{array}{c}\text { USSR } 2.2 .3 \\
\text { TWRS SE } \\
4.2 .1 \\
\text { W-314 SE } \\
4.2 .1 .1 \\
4.2 .1 .3\end{array}$ & $\begin{array}{l}\text { Instrumentation } \\
\text { and Control }\end{array}$ & $\begin{array}{l}\text { Upgrade the CAM annulus leak detectors in DST's and } \\
\text { DCRT's with new models. }\end{array}$ & $\begin{array}{l}\text { Safety Not required for safety. } \\
\text { Compliance 40CFR265.193, detection of leaks to } \\
\text { secondary containment within } 24 \text { hours. } \\
\text { Privatization No privatization requirements } \\
\text { identified. } \\
\text { Conduct of Operations Reduce personnel } \\
\text { exposure, operating, and maintenance costs by } \\
\text { minimizing farm.entry for data collection and } \\
\text { eliminating unreliable instruments. }\end{array}$ \\
\hline $\begin{array}{c}\text { USSR } 2.2 .3 \\
\text { TWRS SE } \\
4.2 .1 \\
\text { W-314 SE } \\
4.2 .1 .1 \\
4.2 .1 .3\end{array}$ & $\begin{array}{l}\text { Instrumentation } \\
\text { and Control }\end{array}$ & $\begin{array}{l}\text { Replace the SpG-WF method of determining DST leak } \\
\text { detection pit leak with better technology. This method } \\
\text { will be applied to a dry pit. }\end{array}$ & $\begin{array}{l}\text { Safety Not required for safety. } \\
\text { Compliance } 40 \text { CFR } 265.193 \text {, detection of leaks to } \\
\text { secondary containment within } 24 \text { hours. } \\
\text { Privatization No privatization requirements } \\
\text { identified. } \\
\text { Conduct of Operations Reduce personnel } \\
\text { exposure, operating, and maintenance costs by } \\
\text { minimizing farm entry for data collection and } \\
\text { eliminating unreliable instruments. }\end{array}$ \\
\hline
\end{tabular}


WHC-SD-W314-RPT-003

Revision 0

\begin{tabular}{|c|c|c|c|}
\hline Section & Category & Description & Requirement \\
\hline $\begin{array}{c}\text { USSR } 2.2 .3 \\
\text { TWRS SE } \\
4.2 .1 \\
\text { W-314 SE } \\
4.2 .1 .1 \\
4.2 .1 .3\end{array}$ & $\begin{array}{l}\text { Instrumentation } \\
\text { and Control }\end{array}$ & $\begin{array}{l}\text { Upgrade the DST leak detection pit radiation detectors to } \\
\text { withstand the physical environment. }\end{array}$ & $\begin{array}{l}\text { Safety Not required for safety. } \\
\text { Compliance } 40 \text { CFR } 265.193 \text {, detection of leaks to } \\
\text { secondary containment within } 24 \text { hours. } \\
\text { Privatization No privatization requirements } \\
\text { identified. } \\
\text { Conduct of Operations Reduce personnel } \\
\text { exposure, operating, and maintenance costs by } \\
\text { minimizing farm entry for data collection and } \\
\text { eliminating unreliable instruments. }\end{array}$ \\
\hline $\begin{array}{c}\text { USSR } 2.2 .3 \\
\text { TWRS SE } \\
4.2 .1 \\
\text { W-314 SE } \\
4.2 .1 .1 \\
4.2 .1 .3\end{array}$ & $\begin{array}{l}\text { Instrumentation } \\
\text { and Control }\end{array}$ & Alarm DST leak detection pit high liquid level. & $\begin{array}{l}\text { Safety Not required for safety. } \\
\text { Compliance No compliance issues identified. } \\
\text { Privatization No privatization requirements } \\
\text { identified. } \\
\text { Conduct of Operations Reduce personnel exposure } \\
\text { and minimize farm entry by automatically sensing } \\
\text { need for pit pumpout. }\end{array}$ \\
\hline $\begin{array}{c}\text { USSR } 2.2 .3 \\
\text { TWRS SE } \\
4.2 .1 \\
\text { W-314 SE } \\
4.2 .1 .1 \\
4.2 .1 .3\end{array}$ & $\begin{array}{l}\text { Instrumentation } \\
\text { and Control }\end{array}$ & Alarm high liquid level in DST's. & $\begin{array}{l}\text { Safety Not required for safety. } \\
\text { Compliance } 40 \text { CFR264.194, appropriate controls } \\
\text { required to eliminate tank overfill. } \\
\text { Privatization No privatization requirements } \\
\text { identified. } \\
\text { Conduct of Operations Provide an engineered } \\
\text { barrier to eliminate operating errors which could } \\
\text { result in tank overfill and spillage of waste. }\end{array}$ \\
\hline
\end{tabular}


WHC-SD-W314-RPT-003

Revision 0

\begin{tabular}{|c|c|c|c|}
\hline Section & Category & Description & Requirement \\
\hline $\begin{array}{c}\text { USSR } 2.2 .3 \\
\text { TWRS SE } \\
4.2 .1 \\
\text { W-314 SE } \\
4.2 .1 .1 \\
4.2 .1 .3\end{array}$ & $\begin{array}{l}\text { Instrumentation } \\
\text { and Control }\end{array}$ & $\begin{array}{l}\text { Replace existing clean out box leak detectors systems } \\
\text { with an operationally testable system. }\end{array}$ & $\begin{array}{l}\text { Safety Not required for safety. } \\
\text { Compliance 40CFR265.193, detection of leaks to } \\
\text { secondary containment within } 24 \text { hours. } \\
\text { Privatization No privatization requirements } \\
\text { identified. } \\
\text { Conduct of Operations Reduce personnel exposure } \\
\text { and operating costs by improving control of waste } \\
\text { transfers and eliminating shutdowns due to false } \\
\text { alarms. }\end{array}$ \\
\hline $\begin{array}{c}\text { USSR } 2.2 .3 \\
\text { TWRS SE } \\
4.2 .1 \\
\text { W-314 SE } \\
4.2 .1 .1 \\
4.2 .1 .3\end{array}$ & $\begin{array}{l}\text { Instrumentation } \\
\text { and Control }\end{array}$ & $\begin{array}{l}\text { Replace existing primary pipeline leak detectors with an } \\
\text { operationally testable system in the DST farms and } \\
\text { DCRT's transfer pits and pipeline encasements. }\end{array}$ & $\begin{array}{l}\text { Safety Not required for safety. } \\
\text { Compliance 40CFR265.193, detection of leaks } \\
\text { and removal from service within } 24 \text { hours. } \\
\text { Privatization No privatization requirements } \\
\text { identified. } \\
\text { Conduct of Operations Reduce personnel exposure } \\
\text { and operating costs by improving control of waste } \\
\text { transfers and eliminating shutdowns due to false } \\
\text { alarms. }\end{array}$ \\
\hline $\begin{array}{c}\text { USSR } 2.2 .3 \\
\text { TWRS SE } \\
4.2 .1 \\
\text { W-314 SE } \\
4.2 .1 .1 \\
4.2 .1 .3\end{array}$ & $\begin{array}{l}\text { Instrumentation } \\
\text { and Control }\end{array}$ & $\begin{array}{l}\text { Verify waste transfer routing through the use of pipeline } \\
\text { valve position indicators, pressure sensors, pipeline flow } \\
\text { monitoring as required on routing between the AN and } \\
\text { AP DST farms and the DCRT's. }\end{array}$ & $\begin{array}{l}\text { Safety Not required for safety. } \\
\text { Compliance } 40 C F R 264.196 \text {, eliminate spills due } \\
\text { to misrouting. } \\
\text { Privatization Supports AN and AP privatization } \\
\text { requirements. } \\
\text { Conduct of Operations Reduce personnel exposure } \\
\text { and cleanup costs by assuring transfers are } \\
\text { executed as planned. }\end{array}$ \\
\hline
\end{tabular}


WHC-SD-W314-RPT-003

Revision 0

\begin{tabular}{|c|c|c|c|}
\hline Section & Category & Description & Requirement \\
\hline $\begin{array}{l}\text { USSR } 2.2 .3 \\
\text { TWRS SE } \\
4.2 .1 \\
\text { W-314 SE } \\
4.2 .1 .1 \\
4.2 .1 .3\end{array}$ & $\begin{array}{l}\text { Instrumentation } \\
\text { and Control }\end{array}$ & $\begin{array}{l}\text { Upgrade the master pump shutdown system to use } \\
\text { operationally testable components and to replace the } \\
\text { relay based approach in the DST farms and SST farms } \\
\text { as specified. }\end{array}$ & $\begin{array}{l}\text { Safety Not required for safety. } \\
\text { Compliance 40CFR } 265.193 \text {, detection of leaks } \\
\text { and shutdown of transfer. } \\
\text { Privatization No privatization requirements } \\
\text { identified. } \\
\text { Conduct of Operations Reduce personnel exposure } \\
\text { and operating costs by improving control of waste } \\
\text { transfers and eliminating shutdowns due to false } \\
\text { alarms. }\end{array}$ \\
\hline $\begin{array}{l}\text { USSR } 2.2 .3 \\
\text { TWRS SE } \\
4.2 .1 \\
\text { W-314 SE } \\
4.2 .1 .1 \\
4.2 .1 .3\end{array}$ & $\begin{array}{l}\text { Instrumentation } \\
\text { and Control }\end{array}$ & $\begin{array}{l}\text { Upgrade the master pump shutdown relay panel in the } \\
242 \text {-A and upgrade and move the panel out of the } 242-S \\
\text { evaporators. }\end{array}$ & $\begin{array}{l}\text { Safety Not required for safety. } \\
\text { Compliance 40CFR265.193, detection of leaks } \\
\text { and shutdown of transfer. } \\
\text { Privatization No privatization requirements } \\
\text { identified. } \\
\text { Conduct of Operations Reduce personnel exposure } \\
\text { and operating costs by improving control of waste } \\
\text { transfers and eliminating shutdowns due to false } \\
\text { alarms. }\end{array}$ \\
\hline $\begin{array}{l}\text { USSR } 2.2 .3 \\
\text { TWRS SE } \\
4.2 .1 \\
\text { W-314 SE } \\
4.2 .1 .1 \\
4.2 .1 .3\end{array}$ & $\begin{array}{l}\text { Instrumentation } \\
\text { and Control }\end{array}$ & $\begin{array}{l}\text { Raw water flow for the AN, AP, AW, AY and DST's } \\
\text { and DCRT's service pits. }\end{array}$ & $\begin{array}{l}\text { Safety Not required for safety. } \\
\text { Compliance No compliance issues identified. } \\
\text { Privatization Supports AN and AP privatization } \\
\text { requirements. } \\
\text { Conduct of Operations Reduce operating costs by } \\
\text { minimizing tank waste. }\end{array}$ \\
\hline
\end{tabular}




\section{WHC-SD-W314-RPT-003}

Revision 0

\begin{tabular}{|c|c|c|c|}
\hline Section & Category & Description & Requirement \\
\hline $\begin{array}{c}\text { USSR } 2.2 .3 \\
\text { TWRS SE } \\
4.2 .1 \\
\text { W-314 SE } \\
4.2 .1 .1 \\
4.2 .1 .3\end{array}$ & $\begin{array}{l}\text { Instrumentation } \\
\text { and Control }\end{array}$ & $\begin{array}{l}\text { Raw water radiation (backflow detection) at the DCRT's } \\
\text { service pit. }\end{array}$ & $\begin{array}{l}\text { Safety Not required for safety. } \\
\text { Compliance } 40 \text { CFR } 265.193 \text {, detection of leaks to } \\
\text { secondary containment within } 24 \text { hours. } \\
\text { Privatization No privatization requirements } \\
\text { identified. } \\
\text { Conduct of Operations Reduce operating costs by } \\
\text { minimizing tank waste. }\end{array}$ \\
\hline $\begin{array}{c}\text { USSR } 2.2 .3 \\
\text { TWRS SE } \\
4.2 .1 \\
\text { W-314 SE } \\
4.2 .1 .1 \\
4.2 .1 .3\end{array}$ & $\begin{array}{l}\text { Instrumentation } \\
\text { and Control }\end{array}$ & Provide leak detection of new piping. & $\begin{array}{l}\text { Safety Not required for safety. } \\
\text { Compliance 40CFR265.193, detection of leaks to } \\
\text { secondary containment within } 24 \text { hours. } \\
\text { Privatization Supports AN and AP privatization } \\
\text { requirements. } \\
\text { Conduct of Operations Reduce personnel exposure } \\
\text { and operating costs by improving control of waste } \\
\text { transfers and eliminating shutdowns due to false } \\
\text { alarms. }\end{array}$ \\
\hline $\begin{array}{c}\text { USSR } 2.2 .3 \\
\text { TWRS SE } \\
4.2 .1 \\
\text { W-314 SE } \\
4.2 .1 .1 \\
4.2 .1 .3\end{array}$ & $\begin{array}{l}\text { Instrumentation } \\
\text { and Control }\end{array}$ & $\begin{array}{l}\text { Tank waste specific gravity, temperature, and liquid } \\
\text { level in the DST's and the DCRT's. }\end{array}$ & $\begin{array}{l}\text { Safety Not required for safety. } \\
\text { Compliance DOE } 5820.2 \mathrm{~A} \text {, monitoring system } \\
\text { requirements. } \\
\text { Privatization No privatization requirements } \\
\text { identified. } \\
\text { Conduct of Operations Appropriate tank } \\
\text { parameters are monitored to assure conduct of } \\
\text { operations and adherence to OSR and other } \\
\text { operating procedures. }\end{array}$ \\
\hline
\end{tabular}


WHC-SD-W314-RPT-003

Revision 0

\begin{tabular}{|c|c|c|c|}
\hline Section & Category & Description & Requirement \\
\hline $\begin{array}{c}\text { USSR } 2.2 .3 \\
\text { TWRS SE } \\
4.2 .1 \\
\text { W-314 SE } \\
4.2 .1 .1 \\
4.2 .1 .3\end{array}$ & $\begin{array}{l}\text { Instrumentation } \\
\text { and Control }\end{array}$ & $\begin{array}{l}\text { Tank primary vapor space pressure in DST's and the } \\
\text { DCRT's. }\end{array}$ & $\begin{array}{l}\text { Safety Not required for safety. } \\
\text { Compliance DOE } 5820.2 \mathrm{~A} \text {, pressure monitoring } \\
\text { requirements. } \\
\text { Privatization No privatization requirements } \\
\text { identified. } \\
\text { Conduct of Operations Tank pressures are } \\
\text { monitored to assure conduct of operations and } \\
\text { adherence to OSR and other operating procedures. }\end{array}$ \\
\hline $\begin{array}{c}\text { USSR } 2.2 .3 \\
\text { TWRS SE } \\
4.2 .1 \\
\text { W-314 SE } \\
4.2 .1 .1 \\
4.2 .1 .3\end{array}$ & $\begin{array}{l}\text { Instrumentation } \\
\text { and Control }\end{array}$ & $\begin{array}{l}\text { Primary ventilation train pre-filter and HEPA filter } \\
\text { differential pressures, exhaust temperature, and exhaust } \\
\text { heater differential pressure for all DST farms except AY } \\
\text { and } A Z \text {, and the } 244-A \text { DCRT. }\end{array}$ & $\begin{array}{l}\text { Safety Not required for safety. } \\
\text { Compliance DOE5820.2A, tank ventilation system } \\
\text { monitoring requirements. } \\
\text { Privatization No privatization requirements } \\
\text { identified. } \\
\text { Conduct of Operations The tank ventilation } \\
\text { systems are monitored to assure conduct of } \\
\text { operations and adherence to OSR and other } \\
\text { operating procedures. }\end{array}$ \\
\hline $\begin{array}{c}\text { USSR } 2.2 .3 \\
\text { TWRS SE } \\
4.2 .1 \\
\text { W-314 SE } \\
4.2 .1 .1 \\
4.2 .1 .3\end{array}$ & $\begin{array}{l}\text { Instrumentation } \\
\text { and Control }\end{array}$ & $\begin{array}{l}\text { Install the WHC "Gaseous Effluent Monitoring System" } \\
\text { at the AW, SY, AN and AP primary ventilation exhaust } \\
\text { stack. }\end{array}$ & $\begin{array}{l}\text { Safety Not required for safety. } \\
\text { Compliance } 40 \text { CFR } 60 \text {, regulated stack } \\
\text { monitoring. } \\
\text { Privatization No privatization requirements } \\
\text { identified. } \\
\text { Conduct of Operations Effluents from the tank } \\
\text { ventilation systems are monitored to assure } \\
\text { adherence to OSR and other operating procedures. }\end{array}$ \\
\hline
\end{tabular}


WHC-SD-W314-RPT-003

Revision 0

\begin{tabular}{|c|c|c|c|}
\hline Section & Category & Description & Requirement \\
\hline $\begin{array}{l}\text { USSR } 2.2 .3 \\
\text { TWRS SE } \\
4.2 .1 \\
\text { W-314 SE } \\
4.2 .1 .1 \\
4.2 .1 .3\end{array}$ & $\begin{array}{l}\text { Instrumentation } \\
\text { and Control }\end{array}$ & $\begin{array}{l}\text { Input DST farm annunciated signals ("Panalarm") into a } \\
\text { centralized monitoring system. }\end{array}$ & $\begin{array}{l}\text { Safety Not required for safety. } \\
\text { Compliance DOE } 5820.2 \mathrm{~A} \text {, alarm and monitoring } \\
\text { system requirements. } \\
\text { Privatization No privatization requirements } \\
\text { identified. } \\
\text { Conduct of Operations Appropriate alarms are } \\
\text { assigned to selected tank parameters to assure } \\
\text { adherence to OSR and other operating procedures } \\
\text { as specified by conduct of operations. }\end{array}$ \\
\hline $\begin{array}{l}\text { USSR } 2.2 .3 \\
\text { TWRS SE } \\
4.2 .1 \\
\text { W-314 SE } \\
4.2 .1 .1 \\
4.2 .1 .3\end{array}$ & $\begin{array}{l}\text { Instrumentation } \\
\text { and Control }\end{array}$ & $\begin{array}{l}\text { Replace the existing "Game-Well" remote alarm } \\
\text { monitoring with alarm displays in the DST farms. }\end{array}$ & $\begin{array}{l}\text { Safety Not required for safety. } \\
\text { Compliance No compliance issues identified. } \\
\text { Privatization No privatization requirements } \\
\text { identified. } \\
\text { Conduct of Operations Supports the development } \\
\text { of enhanced, centralized TMACS operation. }\end{array}$ \\
\hline
\end{tabular}


WHC-SD-W314-RPT-003

Revision 0

\begin{tabular}{|c|c|c|c|}
\hline Section & Category & Description & Requirement \\
\hline $\begin{array}{c}\text { USSR } 2.2 .3 \\
\text { TWRS SE } \\
4.2 .1 \\
\text { W-314 SE } \\
4.2 .1 .1 \\
4.2 .1 .3\end{array}$ & $\begin{array}{l}\text { Instrumentation } \\
\text { and Control }\end{array}$ & $\begin{array}{l}\text { Connect selected existing alarms from the A, BY, C, } \\
\text { SX, and U farms; and CR-271, 242-T, 244-AR, and } \\
\text { 204-AR facilities for input to the TMACS. }\end{array}$ & $\begin{array}{l}\text { Safety Not required for safety. } \\
\text { Compliance DOES820.2A, alarm and monitoring } \\
\text { system requirements. } \\
\text { Privatization No privatization requirements } \\
\text { identified. } \\
\text { Conduct of Operations TMACS is a supervisory } \\
\text { monitor system which has been installed as part of } \\
\text { the tank farms safety initiative. TMACS has } \\
\text { significantly improved conduct of operations and } \\
\text { has reduced surveillance costs. Since TMACS is } \\
\text { installed in most of the tank farms, future work } \\
\text { should capitalize on these recent improvements by } \\
\text { using it as the basis of the overall central } \\
\text { monitoring system. }\end{array}$ \\
\hline $\begin{array}{c}\text { USSR } 2.2 .3 \\
\text { TWRS SE } \\
4.2 .1 \\
\text { W-314 SE } \\
4.2 .1 .1 \\
4.2 .1 .3\end{array}$ & $\begin{array}{l}\text { Instrumentation } \\
\text { and Control }\end{array}$ & $\begin{array}{l}\text { Move selected monitor and controls from the } 242-\mathrm{S} \\
\text { control room. }\end{array}$ & $\begin{array}{l}\text { Safety Not required for safety. } \\
\text { Compliance No compliance issues identified. } \\
\text { Privatization No privatization requirements } \\
\text { identified. } \\
\text { Conduct of Operations Relocation of the identified } \\
\text { signals from the } 242-S \text { control room will allow this } \\
\text { Building to be transferred to the D\&D contractors, } \\
\text { thus reducing operating and other support cost. }\end{array}$ \\
\hline
\end{tabular}


WHC-SD-W314-RPT-003

Revision 0

\begin{tabular}{|c|c|c|c|}
\hline Section & Category & Description & Requirement \\
\hline $\begin{array}{c}\text { USSR } 2.2 .4 \\
\text { TWRS SE } \\
4.2 .1 \\
\text { W-314 SE } \\
4.2 .1 .1 \\
4.2 .1 .3\end{array}$ & Electrical & $\begin{array}{l}\text { Replace existing MCC's, vent and heater control panel } \\
\text { with new units in the } 241-A Y \text { and } 241-A Z \text { Tank Farms } \\
\text { and the } 244-A \text { DCRT. }\end{array}$ & $\begin{array}{l}\text { Safety Not required for safety. } \\
\text { Compliance No compliance issues identified. } \\
\text { Privatization No privatization requirements } \\
\text { identified. } \\
\text { Conduct of Operations Assure electrical systems } \\
\text { will meet OSR requirements for the life of the } \\
\text { facility. }\end{array}$ \\
\hline $\begin{array}{c}\text { USSR } 2.2 .4 \\
\text { TWRS SE } \\
4.2 .1 \\
\text { W-314 SE } \\
4.2 .1 .1 \\
4.2 .1 .3\end{array}$ & Electrical & $\begin{array}{l}\text { Upgrade and/or provide backup power system for the } \\
\text { primary ventilation system and stack monitors for Tank } \\
\text { Farms } 241-\mathrm{AN}, \mathrm{AP} \text {, and } \mathrm{AW} \text {. }\end{array}$ & $\begin{array}{l}\text { Safety Not required for safety. } \\
\text { Compliance DOE } 5820.2 \mathrm{~A} \text {, normal and backup } \\
\text { electrical power. } \\
\text { Privatization No privatization requirements } \\
\text { identified. } \\
\text { Conduct of Operations Assure electrical systems } \\
\text { will meet OSR requirements for the life of the } \\
\text { facility. }\end{array}$ \\
\hline $\begin{array}{c}\text { USSR } 2.2 .4 \\
\text { TWRS SE } \\
4.2 .1 \\
\text { W-314 SE } \\
4.2 .1 .1 \\
4.2 .1 .3\end{array}$ & Electrical & $\begin{array}{l}\text { Replace existing feeder of } 244-\mathrm{S} \text { by providing a new } \\
\text { pad-mounted } 13.8 \mathrm{kV} \text { transformer. }\end{array}$ & $\begin{array}{l}\text { Safety Not required for safety. } \\
\text { Compliance DOE5820.2A, normal and backup } \\
\text { electrical power. } \\
\text { Privatization No privatization requirements } \\
\text { identified. } \\
\text { Conduct of Operations Assure electrical systems } \\
\text { will meet OSR requirements for the life of the } \\
\text { facility. }\end{array}$ \\
\hline
\end{tabular}


WHC-SD-W314-RPT-003

Revision 0

\begin{tabular}{|c|c|c|c|}
\hline Section & Category & Description & Requirement \\
\hline $\begin{array}{c}\text { USSR } 2.2 .4 \\
\text { TWRS SE } \\
4.2 .1 \\
\text { W-314 SE } \\
4.2 .1 .1 \\
4.2 .1 .3\end{array}$ & Electrical & $\begin{array}{l}\text { Provide SST's power systems to support controlled, } \\
\text { clean, and stable and to refeed existing lights and } \\
\text { miscellaneous instrumentation such as TMACS. }\end{array}$ & $\begin{array}{l}\text { Safety Not required for safety. } \\
\text { Compliance DOE5820.2A, normal electrical } \\
\text { power. } \\
\text { Privatization No privatization requirements } \\
\text { identified. } \\
\text { Conduct of Operations Assure electrical systems } \\
\text { will meet OSR requirements for the life of the } \\
\text { facility. }\end{array}$ \\
\hline $\begin{array}{c}\text { USSR 2.2.4 } \\
\text { TWRS SE } \\
4.2 .1 \\
\text { W-314 SE } \\
4.2 .1 .1 \\
4.2 .1 .3\end{array}$ & Electrical & $\begin{array}{l}\text { Spare main circuit breakers for AN, and AW Tank } \\
\text { Farms. }\end{array}$ & $\begin{array}{l}\text { Safety Not required for safety. } \\
\text { Compliance No compliance issues identified. } \\
\text { Privatization No privatization requirements } \\
\text { identified. } \\
\text { Conduct of Operations Provide power flexibility in } \\
\text { support of preventive maintenance to ensure } \\
\text { serviceability for the life of the facility. }\end{array}$ \\
\hline $\begin{array}{c}\text { USSR } 2.2 .4 \\
\text { TWRS SE } \\
4.2 .1 \\
\text { W-314 SE } \\
4.2 .1 .1 \\
4.2 .1 .3\end{array}$ & Electrical & Provide cathodic protection for new piping. & $\begin{array}{l}\text { Safety Not required for safety. } \\
\text { Compliance DOE5820.2A, cathodic protection. } \\
\text { Privatization Provides piping protection on } \\
\text { privatization transfer routes. } \\
\text { Conduct of Operations Assure electrical systems } \\
\text { and piping will meet OSR requirements for the life } \\
\text { of the facility. }\end{array}$ \\
\hline
\end{tabular}




\section{DISTRIBUTION SHEET}

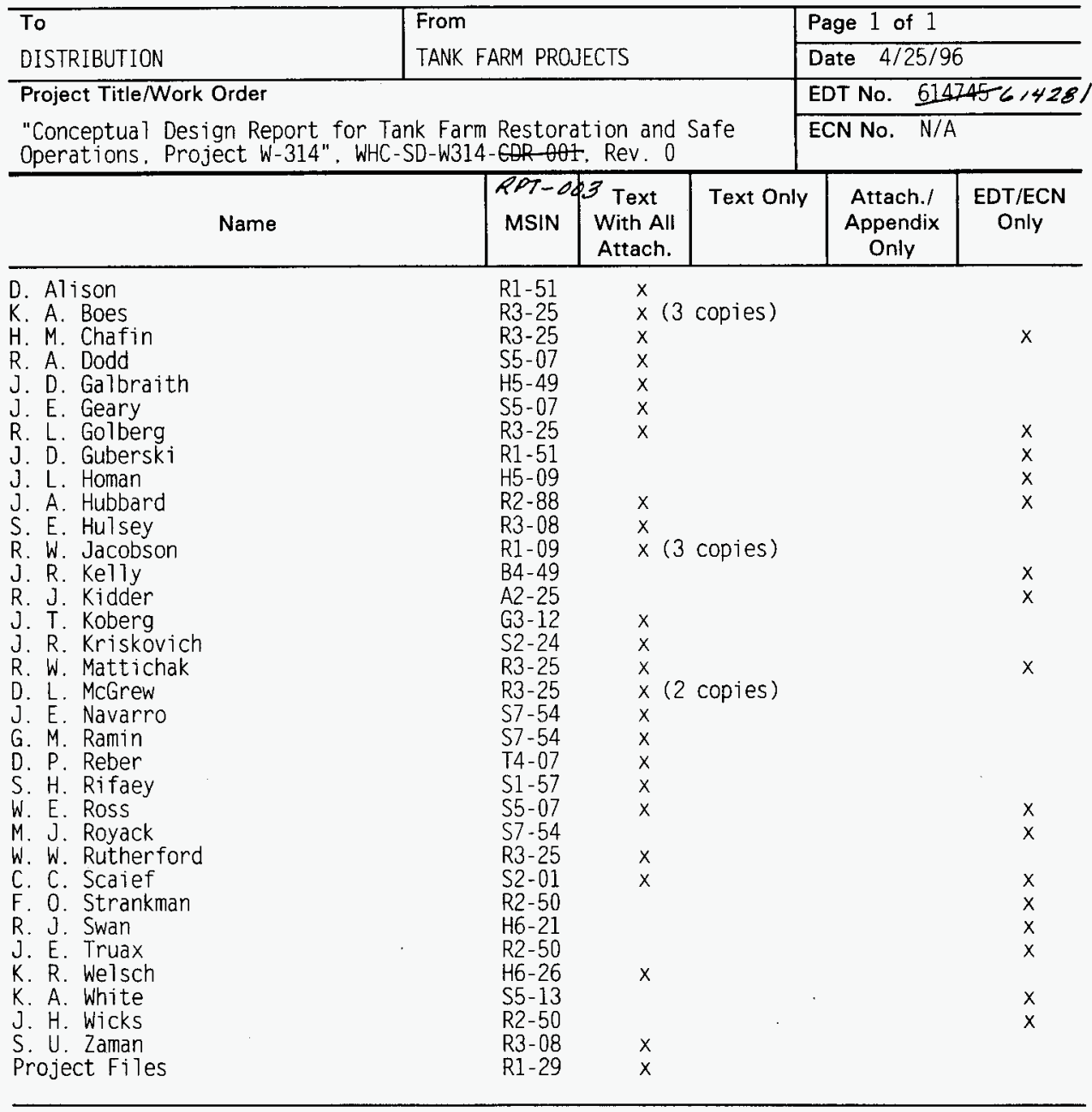

